\title{
Investigating Academic Achievements and Critical Thinking Dispositions of Teacher Candidates*
}

\author{
İbrahim Karagö ${ }^{1}$, Sinan Bekmezci ${ }^{2}$ \\ ${ }^{1}$ Ege University, Faculty of Education, Turkey \\ ${ }^{2}$ Celal Bayar University, Faculty of Education, Turkey \\ Correspondence: İbrahim Karagöl, Ege University, Faculty of Education, Turkey
}

Received: April 17, 2015 Accepted: May 5, $2015 \quad$ Online Published: May 20, 2015

doi:10.11114/jets.v3i4.834 URL: http://dx.doi.org/10.11114/jets.v3i4.834

\begin{abstract}
The aim of this study is to examine the relationship between academic achievements and critical thinking dispositions of teacher candidates in Faculty of Education and to find out whether critical thinking dispositions and academic achievements scores of teacher candidates differ according to different variables. The population consists of the teacher candidates at the Department of Primary School Teaching, Social Science Teaching, Turkish Teaching and Science Teaching at Ege University and Celal Bayar University, Faculty of Education. The study group was determined by convenience sampling method. Scores of teacher candidates obtained through "Critical Thinking Dispositions Inventory" developed by Akbiyık (2002) and students' overall grade point average were used in the study. SPSS 17.00 program was used for analysis of the data. Research design is survey and correlational model. By the findings; critical thinking dispositions of teacher candidates do not differ according to gender, but academic achievement differs according to the gender. Both critical thinking dispositions and academic achievements of teacher candidates do not differ according to type of school. Critical thinking dispositions of teacher candidates differ according to field of study. There is a positive and weak relationship between critical thinking dispositions and academic achievements of teacher candidates.
\end{abstract}

Keywords: Critical thinking, academic achievement, teacher candidates

\section{Introduction}

From past to present, many studies, regulations and development have been carried out with regard to education. Developments in science and technology force education to change and dynamically advancing educational activities require teachers to be better equipped and qualified as the other components of education.

University education is one of important phases of education and it is very important in terms of giving direction to one's future. Therefore, for university students to be achieved, they need to be assisted. Achievement is the output that a person reveals in the face of a mission that he chooses, reaching a conclusion, a behaviour for accomplishing a goal. Academic achievement is defined as the level of knowledge and skills which students gained in academic studies (Ülgen, 1988; cited by Kizılhan, 2011; 55). Achievement factors are the factors that originate from the student himself and outside the student and have an impact on student success in school (Kizllhan, 2011). Those factors affecting academic achievements of students should be identified. There are many environmental factors that affect achievement such as critical thinking (Kökdemir, 2003; Gülveren, 2007; Akbıyık, 2002), mother's and father's education level (Pakır, 2006), adaptation, friends, family support, housing, economic conditions and attitudes of faculty members (Şeker, Çınar \& Özkaya, 2004). In the study by Bozkurt, Gürçay, Kaptan \& Berberoğlu (2000; cited by Şener, Çınar \& Özkaya, 2004), it was concluded that variables such as mother's educational level and type of high school have effect on students' academic achievement. They stated that preventing girls in rural areas from not going to school and increasing the literacy rate of girls would get mothers, who would raise future generations, to be informed and educated and this would contribute to the community catching the information age. So, it is crucial that students are not negatively affected by these factors (Şeker, Çınar \& Özkaya, 2004).

Modern world has made it necessary for individuals to have the thinking skills. Learning to think is gaining importance

${ }^{*}$ This study was presented orally at the Prague 12th International Academic Conference. 
rather than giving and receiving information in teaching. Thus, students who can think, criticize are trained in modern schools and curriculums aimed at gaining students to thinking skills are prepared (Akbiyık, 2002). In this respect, students have been tried to be actively involved in the learning-teaching process particularly in the studies conducted since 2004 in Turkey. They are expected to research, question and present creative ideas. For students to be actively involved in the process, they need not to be indifferent to those around their daily lives and what they are given in the lesson. Contrary to this, they need to think twice on those issues (MEB, 2013).

In the information age we live in, passing the information through thinking filter is getting more and more important. The importance of thinking is reflected in studies relating to thinking. As a result of those studies, it is seen that there is more than one kind of thinking in the literature. One of them is critical thinking. There are many studies in the literature concerning critical thinking (Akar, 2007; Gedik, 2013; Kürüm, 2002; Tümkaya, Aybek \& Aldağ, 2009; Ekici \& Aybek, 2010; Özdemir, 2005; Korkmaz, 2009; Jenkins, 1998; Yenice, 2011; Zayif, 2008; Gülveren, 2007). The examination of the literature shows that there are many definitions of critical thinking. Cüceloğlu (1995: 216) defines critical thinking as an active mental process aiming to be able to understand ourselves and events around us; being aware of our own thinking process, having regard to the opinions of others and applying what we have learned. Sünbül (2011) claims that critical thinking is rational inference, comparing similar situations or realizing the contradiction when analyzing an opinion, comment, beliefs and theory; considering the reliability of information sources based on independent and objective thinking. Scriven \& Paul (2004) define critical thinking as, "that mode of thinking - about any subject, content, or problem - in which the thinker improves the quality of his or her thinking by skillfully taking charge of the structures inherent in thinking and imposing intellectual standards upon them". According to Demirel (2011), critical thinking is the ability of obtaining, evaluating and using information effectively.

There are many factors that affect the strength of the human thinking. Factors affecting critical thinking can gather in two groups. One are cognitive effects brought from inheritance and the other are the factors to which people are exposed through his environment. Intelligence, for example, is an important factor in the development of critical thinking. As intelligence level increases, so does the thinking ability (Kazanc1, 1989). There are many studies in the literature concerning about the relationship between academic achievement and critical thinking dispositions (Akbiylk, 2002; Ip, Lee, Lee, Chau, Wootton \& Chang, 2000; Kökdemir, 2003; Gülveren, 2007; Çevik, 2013). Ay \& Akgöl (2008) reveals that critical thinking skills increase as age increases. Yenice (2011), Zayif (2008) and Gülveren (2007) support that critical thinking dispositions differ according to gender in favor of female students. In an another study, it is seen that students with high critical thinking skills are more successful than the students with low critical thinking skills (Akbıyık \& Seferoğlu, 2006).

In this sense, great responsibilities fall to the teachers in order to train students who can research, question, ask questions and think critically. To make this happen, teachers are first required to have those skills, too. Conducting research about academic achievements and critical thinking dispositions of teacher candidates according to the results is important. During the literature review, not so many studies has been found about the academic achievements and critical thinking dispositions of teacher candidates. For this reason, conducting this study is expected to fill the blanks in literature and provide important benefits to researchers and the study field. The aim of this study is to examine the relationship between academic achievements and critical thinking dispositions of teacher candidates in Faculty of Education and to find out whether critical thinking dispositions and academic achievements scores of teacher candidates differ according to gender, type of high school, field of the study and income level of parents. The hypotheses depending on this purpose were determined as below:

H1: Academic achievement scores of teacher candidates differ according to gender.

$\mathrm{H} 2$ : Critical thinking dispositions of teacher candidates differ according to gender.

H3: Academic achievement scores of teacher candidates differ according to type of high school.

H4: Critical thinking dispositions of teacher candidates differ according to type of high school.

H5: Academic achievement scores of teacher candidates differ according to field of the study.

H6: Critical thinking dispositions of teacher candidates differ according to field of the study.

H7: Academic achievement scores of teacher candidates differ according to income level of parents.

H8: Critical thinking dispositions of teacher candidates differ according to income level of parents.

H9: There is a significant relationship between and academic achievements and critical thinking dispositions of teacher candidates.

\section{Method}

\subsection{Research Model}


Research design was determined as survey model to examine the differences between academic achievements and critical thinking dispositions of teacher candidates according to independent variables. Survey model is used to examine the specific features of a group (Fraenkel, Wallen \& Hyun, 2011). At the same time, the study's design is correlational because the relationship between academic achievements and critical thinking dispositions of teacher candidates was examined. Correlational design is used to examine the relationship between two or more variables without interfering with these variables (Büyüköztürk, Kılıç Çakmak, Erkan Akgün, Karadeniz, \& Demirel, 2013).

\subsection{Population and Sample}

The accessible population of the study consists of the teacher candidates at Ege and Celal Bayar University, Faculty of Education in the 2013-2014 academic year. The sample of the study was determined by convenience sampling method and the study was conducted with 377 teacher candidates. In this sampling, researcher selects participants because they are easy to reach and willing to be studied (Creswell, 2005).

The frequencies are given according to the participants' gender, type of high school, field of study, income level of parents (Table 1).

Table 1. Demographic information of teacher candidates participating in research

\begin{tabular}{llll}
\hline Variable & Groups & $\mathrm{n}$ & $\%$ \\
\hline Gender & Female & 255 & 67,6 \\
& Male & 122 & 32,4 \\
Type of High School & Total & 377 & 100,0 \\
& General High School & 223 & 59,2 \\
& Vocational High School & 22 & 5,8 \\
& Science High School & 4 & 1,1 \\
& Anatolian High School & 102 & 27,1 \\
& Anatolian Teacher High School & 17 & 4,5 \\
& Other & 9 & 2,4 \\
Field of Study & Total & 377 & 100,0 \\
& Primary School Teaching & 75 & 19,9 \\
& Social Science Teaching & 94 & 24,9 \\
& Turkish Teaching & 90 & 23,9 \\
& Science Teaching & 118 & 31,3 \\
& Total & 377 & 100,0 \\
& $0-999$ tl & 94 & 24,9 \\
& $1000-1999$ tl & 175 & 46,4 \\
& $2000-2999$ tl & 73 & 19,4 \\
& 3000 tl and over & 35 & 9,3 \\
& Total & 377 & 100,0 \\
\hline
\end{tabular}

\subsection{Instruments}

As instruments, Critical Thinking Dispositions Inventory developed by Akbıyık (2002) and teacher candidates' overall grade point average were used in the study.

\subsubsection{Critical Thinking Dispositions Inventory}

The scale consists of 30 items. Responses given items are rated as "strongly agree (5)", "agree (4)", "undecided (3)", "disagree (2) "strongly disagree (1)". For every positive item scores between 1-5, for every negative item scores between 5-1 are given. There are items like: "I do not question the causes of the problems I encounter." and "I try to understand other people's perspectives on events." Cronbach alpha reliability coefficient of the scale was found .89 in this research.

\subsubsection{Analyses}

SPSS 17.00 program was used in the analysis of the data. Independent Samples $T$ Test was used to examine the difference between academic achievement scores of teacher candidates according to gender since groups of independent variable's variances were homogeneous and groups of independent variable were normally distributed. Independent Samples $\mathrm{T}$ Test was used to examine the difference between critical thinking dispositions of teacher candidates according to gender since groups of independent variable's variances were homogeneous and groups of independent variable were normally distributed. Kruskal Wallis Test Test was used to examine the difference between academic achievement scores of teacher candidates according to type of high school since the assumptions of parametric tests such as homogeneity of variance, normal distribution, the sample size could not be met. Kruskal Wallis Test Test was used to examine the difference between critical thinking dispositions of teacher candidates according to type of high school since the assumptions of parametric tests such as homogeneity of variance, normal distribution, the sample size could not be met. One Way Anova Test was used to examine the difference between critical thinking dispositions of 
teacher candidates according to field of the study since groups of independent variable's variances were homogeneous and groups of independent variable were normally distributed. Kruskal Wallis Test Test was used to examine the difference between academic achievement scores of teacher candidates according to field of the study since the assumptions of parametric tests such as homogeneity of variance, normal distribution, the sample size could not be met. One Way Anova Test was used to examine the difference between academic achievement scores of teacher candidates according to income level of parents since groups of independent variable's variances were homogeneous and groups of independent variable were normally distributed. One Way Anova Test was used to examine the difference between critical thinking dispositions of teacher candidates according to income level of parents since groups of independent variable's variances were homogeneous and groups of independent variable were normally distributed. Pearson product-moment correlation coefficient was used to examine whether there was a relationship between critical thinking dispositions and academic achievement scores of teacher candidates since both variables were continuous and there was a linear relationship between them.

\section{Results}

The data obtained from the instruments were analyzed. The findings are as follows:

Findings related to "H1: Academic achievement scores of teacher candidates differ according to gender. H2: Critical thinking dispositions of teacher candidates differ according to gender." are shown in the Table 2.

Table 2. Independent Samples t Test Results of Critical Thinking Dispositions and Academic Achievement Points According To Gender

\begin{tabular}{|c|c|c|c|c|c|c|}
\hline & Gender & $\mathrm{N}$ & $\mathrm{M}$ & S.S & $\mathrm{T}$ & $p$ \\
\hline Critical Thinking & Female & 255 & 116,33 & 14,30 & 1,75 &, 81 \\
\hline Dispositions & Male & 122 & 113,43 & 16,35 & & \\
\hline Academic Achiev & $\begin{array}{l}\text { Female } \\
\text { Male }\end{array}$ & $\begin{array}{l}255 \\
122\end{array}$ & $\begin{array}{l}73,53 \\
69,1\end{array}$ & $\begin{array}{l}9,70 \\
10,65\end{array}$ & 4,04 &, 000 \\
\hline
\end{tabular}

As seen in the table, while critical thinking dispositions of teacher candidates do not differ according to gender ( $p>.05$ ), academic achievement differs according to the gender $(\mathrm{p}<.05)$. It can be said that academic achievement of girls is higher than boys. The effect size $d$ is .44, which is, according to Cohen (1988), a small to medium sized "effect". Thus, $\mathrm{H} 1$ hypothesis is accepted, $\mathrm{H} 2$ hypothesis is rejected.

Findings related to "H3: Academic achievement scores of teacher candidates differ according to type of high school." are shown in the table 3.

Table 3. Kruskal-Wallis Test Results Related to Academic Achievement and Teacher Candidates' Type of High School

\begin{tabular}{lllrr}
\hline Type of High School & N & Mean Rank & $\mathrm{x}^{2}$ & $\mathrm{p}$ \\
\hline General High School & 223 & 179,92 & 7,32 &, 198 \\
Vocational High School & 22 & 193,25 & & \\
Science High School & 4 & 266,25 & & \\
Anatolian High School & 102 & 207,66 & & \\
Anatolian Teacher High School & 17 & 188,88 & & \\
Other & 9 & 158,06 & & \\
\hline
\end{tabular}

Academic achievements of teacher candidates do not differ according to type of school ( $\mathrm{p}>.05)$. Accordingly, it can be said that type of high school does not have a significant effect on academic achievement. Thus, $\mathrm{H} 3$ hypothesis is rejected.

Findings related to "H4: Critical thinking dispositions of teacher candidates differ according to type of high school." are shown in the table 4.

Table 4. Kruskal-Wallis Test Results Related to Critical Thinking Dispositions and Teacher Candidates' Type of High School

\begin{tabular}{lllll}
\hline Type of High School & $\mathrm{N}$ & Mean Rank & $\mathrm{x}^{2}$ & $\mathrm{p}$ \\
\hline General High School & 223 & 191,34 & 8,73 &, 120 \\
Vocational High School & 22 & 181,00 & & \\
Science High School & 4 & 36,13 & & \\
Anatolian High School & 102 & 189,15 & & \\
Anatolian Teacher High School & 17 & 187,21 & & \\
Other & 9 & 217,44 & & \\
\hline
\end{tabular}

Critical thinking dispositions of teacher candidates do not differ according to type of school (p>.05). Accordingly, it can be said that type of high school does not have a significant effect on critical thinking dispositions. Thus, H4 hypothesis is rejected. 
Findings related to "H5: Academic achievement scores of teacher candidates differ according to field of the study." are shown in the table 5 .

Table 5. Kruskal-Wallis Test Results Related to Academic Achievement and Teacher Candidates' Field of Study

\begin{tabular}{lllcc}
\hline Field of Study & N & Mean Rank & $x^{2}$ & $p$ \\
\hline Primary School Teaching & 75 & 223,36 & 21,03 &, 000 \\
Social Science Teaching & 94 & 187,24 & & \\
Turkish Teaching & 90 & 206,32 & & \\
Science Teaching & 118 & 155,35 & & \\
\hline
\end{tabular}

Academic achievements of teacher candidates differ according to field of study $(\mathrm{p}<05)$. As seen from the mean rank, while Primary School Teaching is the most successful, Science Teaching is the least successful. Thus, H5 hypothesis is accepted.

Findings related to "H6: Critical thinking dispositions of teacher candidates differ according to field of the study." are shown in the table 7.

Table 6. Means and Standard Deviations Comparing Teacher Candidates' Field of Study

\begin{tabular}{llll}
\hline Critical Thinking Dispositions & & & \\
\hline Field of Study & $\mathrm{n}$ & $\mathrm{M}$ & $\mathrm{SD}$ \\
& & & \\
Primary School Teaching & 75 & 113,85 & 12,87 \\
Social Science Teaching & 94 & 116,42 & 16,73 \\
Turkish Teaching & 90 & 119,88 & 15,46 \\
Science Teaching & 118 & 112,38 & 13,70 \\
\hline
\end{tabular}

Table 7. One Way Anova Results of Teacher Candidates' Critical Thinking Dispositions According to Field of Study

\begin{tabular}{|c|c|c|c|c|c|}
\hline & & Sum of Squares & $\mathrm{df}$ & Mean Squar & F p \\
\hline$\overline{\text { Critical }}$ & Between Groups & 3368,86 & 3 & 1122,95 & $5,137,002$ \\
\hline Thinking & Within Groups & 81544,82 & 373 & 218,62 & \\
\hline Dispositions & Total & 84913,68 & 376 & & \\
\hline
\end{tabular}

Critical thinking dispositions of teacher candidates differ according to field of study $[\mathrm{F}(3-373)=5,137, \mathrm{p} \leq .05]$. Post hoc LSD Test indicates that there are differences between Primary School Teaching and Turkish Teaching $(\mathrm{p}=.009)$, Social Science Teaching and Science Teaching $(\mathrm{p}=.035)$, Turkish Teaching and Science Teaching $(\mathrm{p}=.000)$. Thus, H6 hypothesis is accepted.

Findings related to "H7: Academic achievement scores of teacher candidates differ according to income level of parents. H8: Critical thinking dispositions of teacher candidates differ according to income level of parents." are shown in the table 8 .

Table 8. One Way Anova Results of Teacher Candidates' Critical Thinking Dispositions and Academic Achievement According to Income Level of Parents

\begin{tabular}{llllccc}
\hline & & Sum of Squares & df & Mean Square & F & p \\
\hline Critical & Between Groups & 1190,43 & 3 & 396,81 & 1,768 &, 153 \\
Thinking & Within Groups & 83723,25 & 373 & 224,46 & & \\
Dispositions & Total & 84913,68 & 376 & & & \\
& & & & & & \\
Academic & Between Groups & 120,16 & 3 & 40,06 & \multirow{2}{*}{, 382} &, 766 \\
Achievement & Within Groups & 39158,13 & 373 & 104,98 & & \\
& Total & 39278,30 & 376 & & & \\
\hline
\end{tabular}

Both critical thinking dispositions and academic achievements of teacher candidates do not differ according to income level of parents ( $p>05)$. Accordingly, it can be said that income level of parents does not have a significant effect both on critical thinking dispositions and academic achievement. Thus, both $\mathrm{H} 1$ hypothesis and $\mathrm{H} 2$ hypothesis are rejected.

Findings related to "H9: There is a significant relationship between and academic achievements and critical thinking dispositions of teacher candidates." are shown in the table 9.

Table 9. Relationship between Teacher Candidates' Critical Thinking Dispositions and Academic Achievement

\begin{tabular}{lcc}
\hline \multicolumn{3}{c}{ Academic Achievement } \\
\hline \multirow{3}{*}{ Critical Thinking Dispositions } & Pearson Correlation &, 168 \\
& Sig. &, 001 \\
& $\mathrm{~N}$ & 377 \\
\hline
\end{tabular}

As seen in the table, there is a significant relationship between critical thinking dispositions and academic achievements of teacher candidates $(\mathrm{p}<.05)$. There is a positive and weak relationship between the variables. So, we can tell that 
students who have high academic achievement can have high critical thinking dispositions and vice versa. Thus, H9 hypothesis is accepted.

\section{Discussion}

Results indicate that critical thinking dispositions of teacher candidates do not differ according to gender. Similar to this result, Akar (2007), Gedik (2013), Kürüm (2002), Tümkaya et al. (2009), Ekici \& Aybek (2010), Özdemir (2005), Korkmaz (2009) and Jenkins (1998) found that university students' critical thinking dispositions do not differ according to gender. These results support each other. On the contrary, studies conducted by Yenice (2011), Zayif (2008) and Gülveren (2007) found that there is a significant difference on university students' critical thinking dispositions according to gender in favor of female students. Contradiction between these studies and current study might have occurred because of different sample. In this study, critical thinking dispositions of teacher candidates do not differ according to type of high school and income level of parents. Similar to this result, Akar (2007), Çevik (2013), Zayif (2008) and Gülveren (2007) found that types of high school is not an important variable in terms of critical thinking dispositions as in our study. Therefore, we can say that these studies support each other. However, Kürüm (2002) and Yenice (2011) found that critical thinking dispositions of university students differ according to type of high school. In Kürüm's (2002) study, it was found that students who graduated from Anatolian high school have higher critical thinking dispositions than those who graduated from other types of school.

Result indicate that critical thinking dispositions of teacher candidates do not differ according to income level of parents but do differ according to field of study. Akar (2007) and Özdemir (2005) have similar findings, too. In their studies, critical thinking dispositions of teacher candidates do not differ according to income level of parents. But in Kürüm's (2002) study, critical thinking dispositions of teacher candidates differ according to income level of parents. In this study, critical thinking dispositions of teacher candidates differ according to field of study. This result is similar to results found by Çevik (2013), Kürüm (2002), Gülveren (2007) and Tümkaya et al. (2009). Therefore, we can say that these studies support each other.

The study indicates that academic achievement of teacher candidates do not differ according to types of high school and income level of parents but do differ according to gender and field of study. Accordingly, it can be said that type of high school and income level of parents do not have a significant effect on academic achievement but gender and field of study have a significant effect on academic achievement. Similarly, in Şeker, Çınar \& Özkaya's (2004) and Koç’s (2009) studies, it was found that academic achievement does not differ according to the income level of parents. Therefore, we can say that these studies support each other.

Result of this study revealed that there is a positive and weak relationship between academic achievement and critical thinking dispositions. Correspondingly, Akbiyik (2002), Ip et al. (2000), Kökdemir (2003) and Gülveren (2007) found that students who have high critical thinking dispositions are academically more successful. Accordingly, it can be said that students who have high critical thinking dispositions are academically more successful and vice versa. However, in Çevik's (2013) study, it was found that there is no correlation between critical thinking dispositions and academic achievements of teacher candidates. Contradiction between Çevik's (2013) study and current study might have occurred because of different sample.

The research reveals that critical thinking dispositions of teacher candidates increase academic achievement and vice versa. Therefore, analyzing critical thinking disposition and the variables affecting it is expected to be used as a leverage to manage the faculty effectively and provide important benefits to the researchers and managers. This study is limited with teacher candidates studying in Faculty of Education at Ege and Celal Bayar Universities. To capture the bigger picture, similar studies with large sample can be advised and supported with qualitative data. Critical thinking skills of lecturers can be examined and their effects on the courses can be studied.

\section{References}

Akar, Ü. (2007). The relationship between student teachers' scientific process skills and critical thinking. Master Degree Thesis, Afyonkocatepe University, Institute of Social Sciences, Afyonkarahisar.

Akbıyık, C. (2002). Critical thinking dispositions and academic achievement. Unpublished Master Degree Thesis. Hacettepe University, Institute of Social Sciences, Ankara.

Akbıyık, C., \& Seferoğlu, S. S. (2006). Critical thinking dispositions and academic achievement. Cukurova Universitesi Eğitim Fakultesi Dergisi, 2(32), 90-99.

Ay, S., \& Akgöl, H. (2008). Critical thinking, gender, age and grade level. Kuramsal Eğitimbilim, 1(2), 65-75.

Büyüköztürk, Ş., Kılıç, E., Akgün, Ö., Karadeniz, Ş., \& Demirel, F. (2013). Scientific Research Methods. Ankara: Pegem Akademi.

Çevik, S. (2013). An investigation of the critical thinking dispositions of pre-service teachers at a private non-profit 
university. Master Degree Thesis. Bilkent University, Institute of Educational Sciences, Ankara.

Cohen, J. (1988). Statistical power analysis for the behavioral sciences (2nd Ed.). Hillsdale, NJ: Lawrence Earlbaum Associates.

Creswell, J. W. (2005). Educational research: Planning, conducting, and evaluating quantitative and qualitative research (2nd Ed.). Upper Saddle River: Merrill.

Cüceloğlu, D. (1995). İyi düşün doğru karar ver. İstanbul: Sistem Yayıncılık.

Ekinci, Ö., \& Aybek, B. (2010). Analysis of the empathy and the critical thinking disposition of the teacher candidates. Elem. Educ. Online, 9(2), 816-827.

Fraenkel, J. R., Wallen, N. E., \& Hyun, H. H. (2011). How to design and evaluate research in education (8th Ed.). Boston: McGraw-Hill.

Gedik, H. (2013). Social studies teacher candidates' critical thinking skills. Social and Behavior Sciences, 93(2013), 1020-1024. http://dx.doi.org/10.1016/j.sbspro.2013.09.322

Gülveren. H. (2007). Critical thinking skills of education faculty students and factors influencing critical thinking skills. Unpublished Doctorate Thesis. Dokuz Eylül University Institute of Educational Sciences, İzmir.

Ip, W., Lee, D., Lee, I., Chau, J., Wotton, Y., \& Chang, A. (2000). Dispositions towards critical thinking: A study of Chinese undergraduate nursing students. Journal of Advanced Nursing, 32, 84-90. http://dx.doi.org/10.1046/j.1365-2648.2000.01417.x

Jenkins, E. K. (1998). The significant role of critical thinking in predicting auditing students' performance. J. Educ. Bus., 73(5), 274 -279. http://dx.doi.org/10.1080/08832329809601644

Kazanc1, O. (1989). Eğitimde eleştirici düşünme ve ögretimi. Ankara: Kazancı Hukuk Yayınları.

Kizilhan, P. (2011). The analyses for the effect of classroom climate on the students of primary teaching. Doctorate Thesis. Ankara University, Institute of Educational Sciences, Ankara.

Koç, M. (2009). The effects of the socio-economic factors on the success of the students of vocational and technical education. Master Degree Thesis. Beykent University, Institute of Social Sciences, İstanbul.

Kökdemir, D. (2003). Decision making and problem solving under uncertainty. Unpublished Doctorate Thesis, Ankara University, Institute of Social Sciences, Ankara.

Korkmaz, Ö. (2009). Teachers' critical thinking level and dispositions. Ahi Evran University Kirşehir J. Educ., 10(1), $1-13$.

Kürüm, D. (2002). Critical thinking abilities of teacher trainees. Unpublished Master Degree Thesis. Anadolu University, Institute of Educational Sciences, Eskişehir.

MEB (2013). İlköğretim okulları fen bilimleri dersi öğretim programı. Ankara: MEB Talim ve Terbiye Kurulu Başkanlığı.

Özdemir, S. M. (2005). An evaluation of university students' critical thinking skills with some variables. J. Turk. Educ. Sci., 3(3), 297-314.

Pakir, F. (2006). The effects on the success in the university entrance exam of the students who graduated from high school of which features on family social-economic and demografic. Master Degree Thesis. Van $100^{\text {th }}$ Year University, Institute of Social Sciences, Van.

Scriven, M., \& Paul, R. (2004). Defining critical thinking. Retrieved from 10/08/2014 http://www.criticalthinking.org/pages/defining-critical-thinking/766.

Şeker, R., Çınar, D., \& Özkaya, A. (2004). Effects of environmental factors on the success rate of university student. XIII. National Educational Sciences Congress, İnönü University, Faculty of Education, Malatya.

Sünbül, A. M. (2011). Öğretim ilke ve yöntemleri. Konya: Çizgi Kitabevi.

Tümkaya, S., Aybek, B., \& Aldağ, H. (2009). An investigation of university students' critical thinking disposition and perceived problem solving skills. Eur. J. Educ. Res., 36, 57-74.

Yenice, N. (2011). Investigating pre-service science teachers' critical thinking dispositions and problem solving skills in terms of different variables, Educational Research and Reviews, 6, 497-508.

Zayif, K. (2008). Critical thinking dispositions of pre-service teachers. Unpublished Master Degree Thesis, Abant İzzet Baysal University, Institute of Social Sciences, Bolu.

\section{(cc) BY}

This work is licensed under a Creative Commons Attribution 3.0 License. 